\title{
STUDY ON EFFECTS OF WHEATGRASS (TRITICUM AESTIVUM) JUICE ON SERUM TRIGLYCERIDE OF EXPERIMENTALLY INDUCED HYPERCHO- LESTEROLAEMIC MALE LONG EVANS RAT
}

\author{
AFROZ RD ${ }^{1}$, NURUNNABI ASM ${ }^{2}$, HOSSAIN MZ $^{3}$, KHAN MI $^{4}$, PARVIN $^{5}$, RAHMAN H ${ }^{6}$
}

\begin{abstract}
:
Context: An experimental study was designed to observe the effect of wheatgrass (Triticum aestivum) juice on serum triglyceride on experimentally induced hypercholesterolaemic rats.

Materials \& Methods: The experiment was carried out in the Department of Pharmacology \& Therapeutics, Dhaka Medical College, Dhaka, from July, 2009 to June, 2010. A total number of 48 healthy adult male Long Evans rats (Norwegian strain), age ranging from 90-120 days, and weighing from 140-200 grams were used for the study. 6 rats were taken in each group of total 8 groups treated differently with 1 control group. Rats of the first 5 groups were sacrificed at $29^{\text {th }}$ day and their serum triglyceride levels were measured. Rest of the rats were sacrificed at $57^{\text {th }}$ day and their serum triglyceride levels were measured.
\end{abstract}

Results: The mean serum concentration of total cholesterol of $10 \mathrm{ml} / \mathrm{kg}$ grass juice fed normal rats was decreased by $26.79 \%$ than that of the laboratory diet fed control group. The result was statistically significant $(P<0.001)$. The mean concentration of serum triglyceride of the group of rats treated with $10 \mathrm{ml} / \mathrm{kg}$ grass juice and $1 \%$ cholesterol diet were decreased by $38.04 \%$ than that of the hypercholesterolaemic control group, which was also statistically significant $(P<0.001)$. The mean serum concentration of triglyceride of the hypercholesterolaemic rats treated with $10 \mathrm{ml} / \mathrm{kg}$ grass juice for 28 days were decreased by $25.73 \%$, and in hypercholesterolaemic rats treated with $20 \mathrm{ml} / \mathrm{kg}$ grass juice for 28 days were decreased by $34.81 \%$, both of which were statistically highly significant $(P<0.001)$. The mean serum concentration of triglyceride of the hypercholesterolaemic rats treated with $0.14 \mathrm{mg} / \mathrm{kg}$ Atorvastatin for 28 days were found to be decreased by $32.90 \%$ than that of hypercholesterolemic control group, which was statistically highly significant $(P<0.001)$.

Conclusion: The present study provides the initial step for demonstrating the lipid lowering effects of wheatgrass (Triticum aestivum) juice at hyperlipidaemic state. Further studies with high technical back-up are recommended.

Key words: Wheatgrass Juice, Hyperlipidaemia, Serum triglyceride, Long Evans Rat.

J Dhaka Med Coll. 2012; 21(2) : 197-203.

\section{Introduction:}

Excess in serum triglyceride acts as a risk factor of atherosclerosis like cholesterol ${ }^{1}$. Fresh wheatgrass (Triticum aestivum Linn.) juice showed potential lipid lowering effect on normal rats in different experimental settings ${ }^{2-4}$. It is used as a health improving adjuvant in several diseases including coronary artery disease in India as folk medicine ${ }^{2}$. In the Western world, it is used as merely nutritional supplement to curative agent for last 50 years ${ }^{3}$. In the molecular level, chlorophyll is very similar to haemoglobin. This allows wheatgrass to quickly move into the blood system through the liver to

1. Dr. Rokhsana Dil Afroz, Lecturer, Department of Pharmacology \& Therapeutics, Shaheed Suhrawardy Medical College, Dhaka.

2. Dr. Abu Sadat Mohammad Nurunnabi, Lecturer, Department of Anatomy, Dhaka Medical College, Dhaka.

3. Dr. Mohammad Zaid Hossain, Assistant Professor of Medicine, Dhaka Medical College Hospital. Dhaka.

4. Prof. Md. Ismail Khan, Professor and Head, Department of Pharmacology \& Therapeutics, Dhaka Medical College, Dhaka.

5. Dr. Shamima Parvin, Assistant Professor, Department of Biochemistry, Sir Salimullah Medical College, Dhaka.

6. Dr. Hasanur Rahman, Assistant Professor, Department of Pharmacology \& Therapeutics, Dhaka Medical College, Dhaka.

Correspondence: Dr. Rokhsana Dil Afroz, Lecturer, Department of Pharmacology \& Therapeutics, Shaheed Suhrawardy Medical College, Dhaka. 
distribute its positive effects ${ }^{5}$. However, to the best of our knowledge, study on the lipid lowering effect of wheatgrass juice in hyperlipidaemic condition has not been done in our country previously. Hence, the current study was designed to observe the lowering effect on excess serum triglyceride by wheatgrass (T. aestivum) juice on experimentally induced hypercholesterolaemic rats.

\section{Materials:}

1. Animals: The experiments was carried out upon Long Evans Rats (Rattus rattus), which were obtained from Bangladesh Council of Scientific and Industrial Research (BCSIR), Dhaka. A total number of 48 adult male rats, aging 2-3 months and weighing about 140-200 gm. were included in this study. They were kept in the animal house of the Department of Pharmacology \& Therapeutics, Dhaka Medical College, Dhaka. The rats were kept in cages, acclimatized at $26-29^{\circ} \mathrm{C}$ and humidity, with a 12 hour light and dark cycle. They were allowed free access to standard laboratory diet and water ad libitum. Animals were randomly distributed into eight (8) groups having six (6) rats each.

\section{Drugs and chemicals:}

a) Fresh common wheat (Triticum aestivum) grass juice: The grass of $T$. aestivum used in this study was grown in the roof top garden. When grass was about 6 inches tall, it was cut $1 / 2$ inch above the surface of soil. Twenty grams of harvested fresh grass was grounded by grinder with $10 \mathrm{ml}$ of sterile water and the juice was squeezed out through four layers of wet muslin cloth. The filtrate was made to $20 \mathrm{ml}$ final volume with sterile water and administered as grass juice. Each day the fresh juice was prepared prior to administration.

b) Distilled water;

c) Standard laboratory diet;

d) Fatty mixture: 1\% cholesterol diet was prepared by dissolving $1 \mathrm{gm}$ of cholesterol in $100 \mathrm{ml}$ of olive oil, according to Jesmin $(2006)^{6}$.

3. Kits for the estimation of serum cholesterol: Serum cholesterol was estimated by cholesterol liquicolor CHOD-PAP-Method
(Enzymatic colorimetric test with lipid clearing factor).

\section{Methods:}

The experiment was carried out in the Department of Pharmacology \& Therapeutics, Dhaka Medical College, Dhaka, from July, 2009 to June, 2010. A total number of 48 healthy adult male Long Evans rats (Norwegian strain), age ranging from 90-120 days, and weighing from 140-180 grams, were used for the present study.

\section{Experiment design:}

Group A: This control group consists of six rats received standard laboratory diet and distilled water for 28 days.

Group B: This group of rats was fed standard laboratory diet, distilled water and $10 \mathrm{ml} / \mathrm{kg} 1 \%$ cholesterol diet through feeding tube for 28 days, according to Amin (2009) ${ }^{7}$.

Group C: This group was fed standard laboratory diet and $10 \mathrm{ml} / \mathrm{kg}$ grass juice.

Group D: This hypercholesterolaemic control group received standard laboratory diet and $10 \mathrm{ml} / \mathrm{kg} 1 \%$ cholesterol diet for 28 days.

Group E: This group had received $1 \%$ cholesterol diet along with $10 \mathrm{ml} / \mathrm{kg}$ fresh wheat grass juice to observe the preventive effect of grass juice.

Group F: This group received $10 \mathrm{ml} / \mathrm{kg} 1 \%$ cholesterol diet for 28 days followed by $10 \mathrm{ml} /$ $\mathrm{kg}$ fresh grass juice for next 28 days.

Group G: This group was fed $10 \mathrm{ml} / \mathrm{kg} 1 \%$ cholesterol diet for 28 days followed by $20 \mathrm{ml} /$ $\mathrm{kg}$ fresh grass juice for next 28 days.

Group H: This group received $10 \mathrm{ml} / \mathrm{kg} 1 \%$ cholesterol diet for 28 days followed by $0.14 \mathrm{mg} /$ $\mathrm{kg}$ Atorvastatin (a lipid lowering agent) for next 28 days, according to Jesmin $(2006)^{6}$.

\section{Experiment I:}

This part of the experiment was carried out on first three groups of rats to observe the effect of $1 \%$ cholesterol diet and grass juice on serum cholesterol of normal rat. 


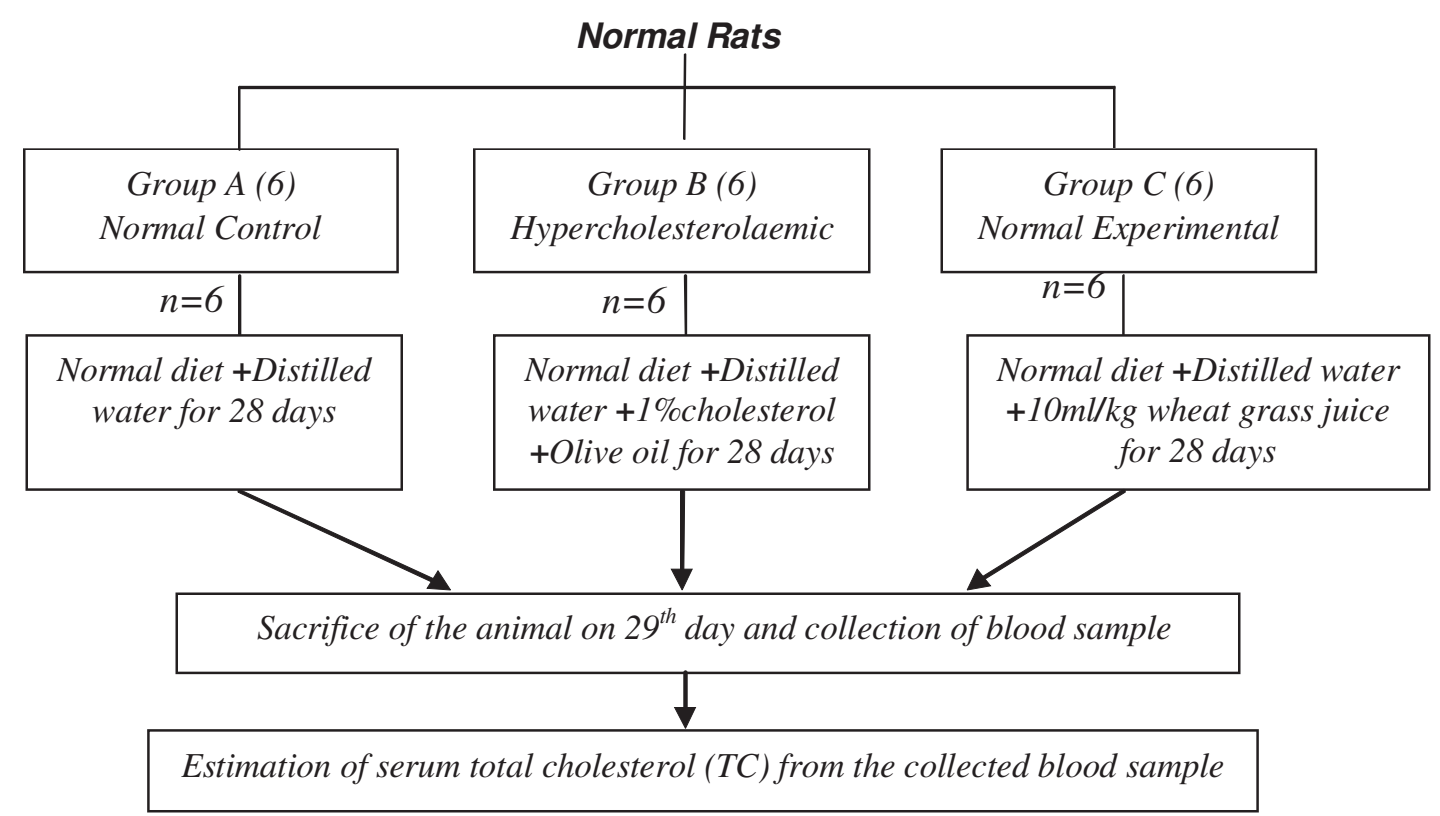

Fig.-1: Flow Chart of Experiment-I

\section{Experiment II:}

The rats of the experiment-II were fed $1 \%$ cholesterol diet $10 \mathrm{ml} / \mathrm{kg}$ or $1 \mathrm{ml} / 100 \mathrm{gm}$ of body weight for 28 days in order to elevate plasma cholesterol level, according to Amin (2009) ${ }^{7}$.

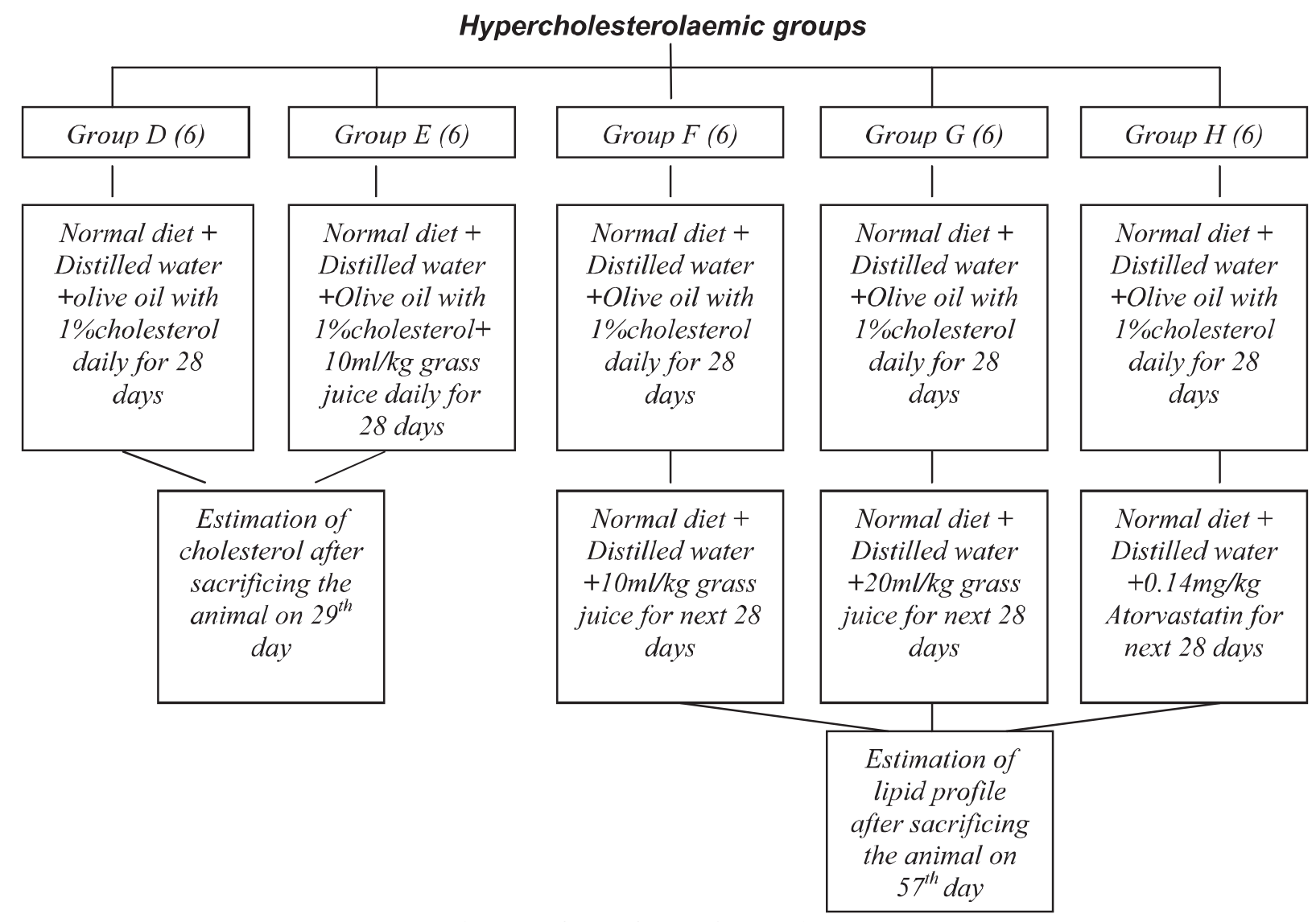

Fig. 2: Flow Chart of Experiment-II 
Each rat was fasted for 18 hours before sacrifice and collecting blood sample. They were given only water ad libitum during the fasting period. All animals were sacrificed under ketamin anaesthesia and blood samples were taken directly from the heart. Samples were collected in the test tubes. These were kept slanting position till blood had clotted. Serum was separated from the clot after centrifugation in the centrifuge machine. Serum was collected in small test tubes and kept at $0^{\circ} \mathrm{C}$. Then the serum was analyzed by the lipid profile kit.

Ethical Clearance: The present study was approved by the Ethical Review Committee of Dhaka Medical College, Dhaka.

\section{Results:}

Experiment-I:

Effect of 1\% cholesterol diet on serum triglyceride of rats: The mean concentration of serum total cholesterol was found to be increased by $49.85 \%$ in rats treated with $1 \%$ cholesterol diet compared to the rats fed normal diet, which was statistically highly significant $(\mathrm{P}<0.001)$ (Table-I, Fig. 3).

Effect of wheat grass juice on serum triglyceride of normal rats: The mean serum concentration of total cholesterol of $10 \mathrm{ml} / \mathrm{kg}$ grass juice fed normal rats was decreased by $26.79 \%$ than that of the laboratory diet fed control group. The result was statistically significant $(\mathrm{P}<0.001)$ (Table-I, Fig. 3).

\section{Experiment-II:}

Effect of grass juice $(10 \mathrm{ml} / \mathrm{kg})$ when taken along with 1\% cholesterol diet: The mean concentration of serum triglyceride of the group of rats treated with $10 \mathrm{ml} / \mathrm{kg}$ grass juice and $1 \%$ cholesterol diet were decreased by $38.04 \%$ than that of the hypercholesterolaemic control group, which was statistically significant $(\mathrm{P}<0.001)$ (Table-II, Fig. 4).

Effect of grass juice $(10 \mathrm{ml} / \mathrm{kg})$ on hypercholesterolaemic rats: The mean serum concentration of triglyceride of the hypercholesterolaemic rats treated with $10 \mathrm{ml} /$ $\mathrm{kg}$ grass juice for 28 days were decreased by $25.73 \%$, which was statistically highly significant $(\mathrm{P}<0.001)$ (Table-II, Fig. 4).

Effect of grass juice $(20 \mathrm{ml} / \mathrm{kg})$ on hypercholesterolaemic rats: The mean serum concentration of triglyceride of the hypercholesterolaemic rats treated with $20 \mathrm{ml} /$ $\mathrm{kg}$ grass juice for 28 days were decreased by $34.81 \%$, which was statistically highly significant $(\mathrm{P}<0.001)$ (Table-II, Fig. 4).

Effect of Atorvastatin $(0.14 \mathrm{mg} / \mathrm{kg}$ ) on hypercholesterolaemic rats: The mean serum concentration of triglyceride of the hypercholesterolaemic rats treated with $0.14 \mathrm{mg} / \mathrm{kg}$ Atorvastatin for 28 days were found to be decreased by $32.90 \%$ than that of hypercholesterolemic control group, which was statistically highly significant $(\mathrm{P}<0.001)$ (TableII, Fig. 4).

Table-I

Serum triglyceride levels in different group of rats in Experiment I

\begin{tabular}{lcccc}
\hline & & TG $(\mathrm{mg} / \mathrm{dl})$ & $\mathrm{P}$ & $\begin{array}{c}\text { Percent } \\
\text { change } \\
\text { Group }\end{array}$ \\
\hline A & $\mathrm{n}$ & $($ Mean $\pm \mathrm{SD})$ & value & (Mean) \\
B & 6 & $70.65 \pm 3.05$ & B vs A $0.0001^{* * *}$ & +49.85 \\
C & 6 & $105.62 \pm 3.81$ & C vs A $0.0001^{* * *}$ & 26.79 \\
\hline
\end{tabular}

Comparison of serum triglyceride levels between groups were done by unpaired Student's ' $\mathrm{t}$ ' test. $* * *=$ Significant at $\mathrm{P}<0.001$.

Group A : Control

Group B : Hypercholesterolaemic

Group C : Laboratory diet plus grass juice 
Comparison of the effects of two different doses $(10 \mathrm{ml} / \mathrm{kg}$ and $20 \mathrm{ml} / \mathrm{kg})$ of grass juice: The serum triglyceride of the hypercholesterolaemic rat group treated with $20 \mathrm{ml} /$ $\mathrm{kg}$ grass juice for 28 days was found to decrease more by $11.88 \%$ than that of the hypercholesterolemic rat group treated with $10 \mathrm{ml} / \mathrm{kg}$ grass juice for the same period, which was statistically highly significant $(\mathrm{P}<0.001)$ (Table-III, Fig. 4).
Comparison of the effects of the wheat grass juice $(20 \mathrm{ml} / \mathrm{kg})$ to that of with Atorvastatin (0.14 $\mathbf{m g} / \mathbf{k g}):$ In the present study, the reduction of serum triglyceride with the dose level of $20 \mathrm{ml} / \mathrm{kg}$ of grass juice (34.81\%) was found almost similar to that of Atorvastatin (32.90\%). The result statistically was not significant (Table-IV, Fig. 4).

Table-II

Serum triglyceride levels in different group of rats in Experiment II

\begin{tabular}{llccc}
\hline Group & $\mathrm{n}$ & $\begin{array}{c}\text { TG }(\mathrm{mg} / \mathrm{dl}) \\
(\text { Mean } \pm \mathrm{SD})\end{array}$ & $\begin{array}{c}\mathrm{P} \\
\text { value }\end{array}$ & $\begin{array}{c}\text { Percent change } \\
\text { (Mean) }\end{array}$ \\
\hline $\mathrm{D}$ & 6 & $105.62 \pm 3.81$ & & \\
$\mathrm{E}$ & 6 & $65.37 \pm 2.91$ & E vs D 0.0001 & \\
$\mathrm{F}$ & 6 & $78.33 \pm 3.99$ & $\mathrm{~F}$ v D 0.0001 & 38.04 \\
$\mathrm{G}$ & 6 & $68.82 \pm 2.23$ & G vs D 0.0001 & 25.73 \\
$\mathrm{H}$ & 6 & $70.72 \pm 4.06$ & H vs D 0.0001 & 34.81 \\
\hline
\end{tabular}

Comparison of serum triglyceride levels between groups were done by unpaired Student's 't' test. $* * *=$ Significant at $\mathrm{P}<0.001$.

Group D : Hypercholesterolaemic

Group E : 1\% cholesterol diet plus grass juice

Group $\mathrm{F}: 1 \%$ Cholesterol followed by $10 \mathrm{ml} / \mathrm{kg}$ grass juice

Group G : $1 \%$ Cholesterol followed by $20 \mathrm{ml} / \mathrm{kg}$ grass juice

Group H : 1\%Cholesterol followed by Atorvastatin

Table-III

Serum triglyceride levels in the groups of rats taken two different doses $(10 \mathrm{ml} / \mathrm{kg}$ and $20 \mathrm{ml} / \mathrm{kg})$ of grass juice in Experiment II

\begin{tabular}{llccc}
\hline Group & $\mathrm{n}$ & $\begin{array}{c}\text { TG }(\mathrm{mg} / \mathrm{dl}) \\
(\text { Mean } \pm \text { SD) }\end{array}$ & $\begin{array}{c}\text { P } \\
\text { value }\end{array}$ & $\begin{array}{c}\text { Percent change } \\
\text { (Mean) }\end{array}$ \\
\hline $\mathrm{F}$ & 6 & $78.33 \pm 3.99$ & & \\
$\mathrm{G}$ & 6 & $68.82 \pm 2.23$ & $0.0001^{* * *}$ & 11.88 \\
\hline
\end{tabular}

Comparison of serum triglyceride levels between group $\mathrm{G}$ and group $\mathrm{F}$ was done by unpaired Student's ' $\mathrm{t}$ ' test. $* * *=$ Significant at $\mathrm{P}<0.001$

Group F : $1 \%$ Cholesterol followed by $10 \mathrm{ml} / \mathrm{kg}$ grass juice

Group G : $1 \%$ Cholesterol followed by $20 \mathrm{ml} / \mathrm{kg}$ grass juice

\section{Table-IV}

Serum triglyceride levels in the groups of rats taken higher dose $(20 \mathrm{ml} / \mathrm{kg})$ of grass juice to that of Atorvastatin in Experiment II

\begin{tabular}{lllcc}
\hline Group & $\mathrm{n}$ & $\begin{array}{c}\text { TG }(\mathrm{mg} / \mathrm{dl}) \\
(\text { Mean } \pm \text { SD) }\end{array}$ & $\begin{array}{c}\text { P } \\
\text { value }\end{array}$ & $\begin{array}{c}\text { Percent change } \\
\text { (Mean) }\end{array}$ \\
\hline $\mathrm{G}$ & 6 & $68.82 \pm 2.23$ & & \\
$\mathrm{H}$ & 6 & $70.72 \pm 4.06$ & $0.339^{\text {ns }}$ & +2.93 \\
\hline
\end{tabular}

Comparison of serum triglyceride levels between group $\mathrm{H}$ and group $\mathrm{G}$ was done by unpaired Student's 't' test. $\mathrm{ns}=$ Not significant.

Group G : $1 \%$ Cholesterol followed by $20 \mathrm{ml} / \mathrm{kg}$ grass juice

Group $\mathrm{H} \quad: 1 \%$ Cholesterol followed by Atorvastatin 


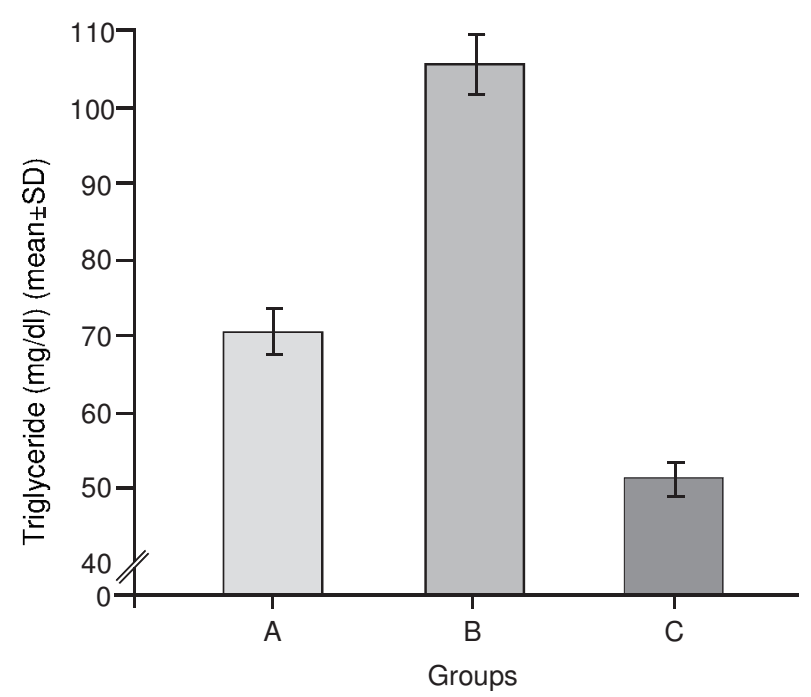

Fig. 3: Serum triglyceride levels in different group of rats in Experiment-I

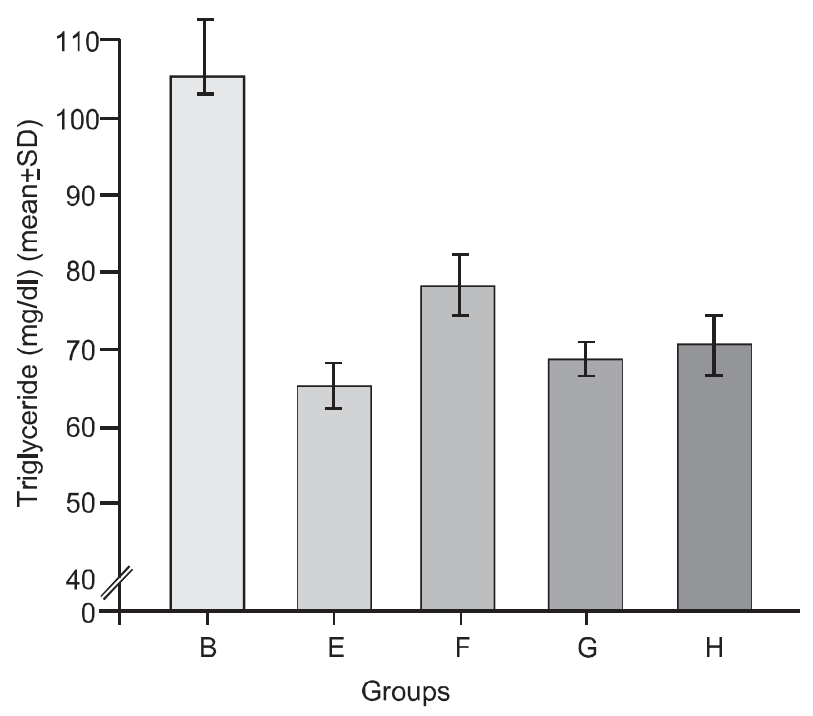

Fig. 4. Serum triglyceride levels in different group of rats in Experiment II.

\section{Discussion:}

The present study was carried out to evaluate the effect of fresh juice of Triticum aestivum grass on serum triglyceride levels. Hyperlipidaemia was induced in rats by administration of $10 \mathrm{ml} /$ $\mathrm{kg}$ body weight olive oil with $1 \%$ cholesterol through feeding tube for 28 days. Hyperlipidaemia was evident with a significant $(\mathrm{P}<0.001)$ increase in serum TCL, LDL and TG levels. Besides, serum HDL level significantly $(\mathrm{P}<0.01)$ decreased. Akter $(1991)^{8}$, Lata et al. $(1991)^{9}$, Anita \& Okokon $(2005)^{10}$, Jesmin $(2006)^{6}$ and Amin (2009) ${ }^{7}$ achieved similar effect on lipid levels by administering similar hyperlipidaemic diet. The results of their studies are more or less in agreement with that of the present study. The group of normal rats that took $10 \mathrm{ml} / \mathrm{kg}$ grass juice had shown significant reduction in serum triglyceride. The result was in full agreement with that of Kothari et al. (2008) ${ }^{2}$. Administration of grass juice along with cholesterol diet also showed significant reduction of serum triglyceride $(\mathrm{P}<0.001)$ than the hypercholesterolaemic group. It indicates preventive role of grass juice against increased triglyceride in blood. Moreover, the lipid lowering effect of grass juice in the present study was found to be dose dependant. In higher dose level $(20 \mathrm{ml} / \mathrm{kg})$ of grass juice the lipid lowering effect was much more evident than that with lower dose $(10 \mathrm{ml} /$ $\mathrm{kg})$. Kothari et al. (2008) $)^{2}$ also observed such changes in lipid parameters in dose related manner. In the present study, the reduction of serum triglyceride with the dose level of $20 \mathrm{ml} /$ $\mathrm{kg}$ of grass juice $(34.81 \%)$ was found almost similar to that of Atorvastatin (32.90\%). However, the present study did not address the mechanisms by which grass juice produce lipid lowering effect. In fact, it is yet to be defined. However, several speculations have been made. The presence of alkaloids, tannins, saponins and sterols, as had been revealed by the preliminary phytochemical analysis may responsible for the lipid lowering effect of the wheat grass juice ${ }^{2}$.

\section{Conclusion:}

The present study provides the initial step for demonstrating the lipid lowering effect of fresh grass juice of Triticum aestivum at hyperlipidaemic state. To the best of our knowledge, any study on the lipid lowering effect of wheat grass juice in hyperlipidaemic condition has not been done in our country or in abroad previously. Therefore, the result could not be correlated further with those of others. Further investigations are recommended to reconfirm and identify the hypolipidaemic active principles and elucidate their mechanism of action. Toxicological studies should also be undertaken before any clinical use. 


\section{References:}

1. Ross R. Atherosclerosis - an inflammatory disease. N Engl J Med 1999; 340(2): 115-26.

2. Kothari S, Jain AK, Mehta SC, Tonpay SD. Effect of fresh Triticum aestivum grass juice on lipid profile of normal rats. Indian J Pharmacol 2008; 40(5): 235-6.

3. Wikipedia. Wheatgrass. Available from: http:// en.wikipedia.org/wiki/Wheatgrass [Retrieved on April 2, 2012].

4. Padalia S, Drabu S, Raheja I, Gupta A, Dhamija M. Multitude potential of wheatgrass juice (Green Blood): an overview. Chron Young Sci 2010; 1(2): 23-8.

5. Parkinson S. Natural Remedies - Wheatgrass. Natural Medicine. Available from: http:// suite $101 . \mathrm{com} /$ article / homeopathic-remedieswheatgrass-a210673 [Retrieved on April 7, 2012].
6. Jesmin S. Effects of Ctharanthus roseus Linn. on serum lipid profile in fat fed rats. [Thesis]. Dhaka: University of Dhaka; 2006.

7. Amin R. Study of the effect of Ganoderma Lucidum on serum lipid profile of hypercholesterolaemic rats. [Thesis]. Dhaka: University of Dhaka; 2009.

8. Akter R. Study of the effect of garlic on blood sugar and serum cholesterol level in normal rats and serum cholesterol level in fat fed rats. [Thesis]. Dhaka: University of Dhaka; 1982.

9. Lata S, Saxena KK, Bhasin V, Saxena RS, Kumar A, Srivastava VK. Beneficial effects of Allium sativum, Allium cepa and Commiphora mukul on experimental hyperlipidemia and atherosclerosis - a comparative evaluation. J Postgrad Med 1991; 37(3): 132-5.

10. Anita BS, Okokon JE. Effect of leaf juice of Catharanthus roseus Linn.) on cholesterol, triglyceride and lipoprotein levels in normal rats. Ind J Pharmacol 2005; 37(6): 401-2. 